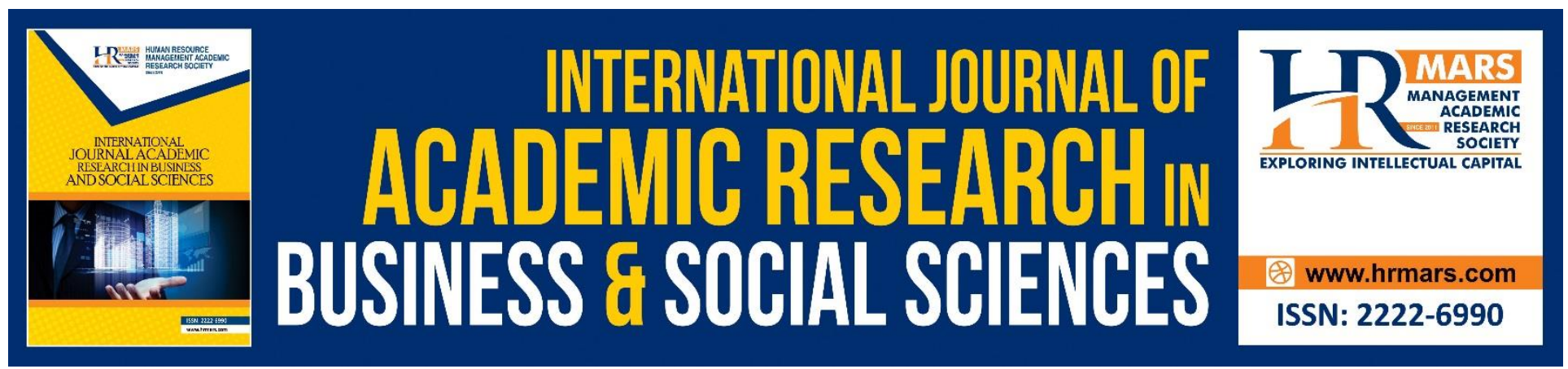

\title{
Assessing the Effect of Sales Force Automation on Sales Force Performance in the Sekondi-Takoradi Metropolis, Ghana
}

\section{Nuhu Alhassan}

To Link this Article: http://dx.doi.org/10.6007/IJARBSS/v8-i9/4675

DOI: $\quad 10.6007 /$ IJARBSS/v8-i9/4675

Received: 14 August 2018, Revised: 29 Sept 2018, Accepted: 05 Oct 2018

Published Online: 15 October 2018

In-Text Citation: (Alhassan, 2018)

To Cite this Article: Alhassan, N. (2018). Assessing the Effect of Sales Force Automation on Sales Force Performance in the Sekondi-Takoradi Metropolis, Ghana. International Journal of Academic Research in Business and Social Sciences, 8(9), 1004-1014.

Copyright: (C) 2018 The Author(s)

Published by Human Resource Management Academic Research Society (www.hrmars.com)

This article is published under the Creative Commons Attribution (CC BY 4.0) license. Anyone may reproduce, distribute, translate and create derivative works of this article (for both commercial and non-commercial purposes), subject to full attribution to the original publication and authors. The full terms of this license may be seen at: http://creativecommons.org/licences/by/4.0/legalcode

Vol. 8, No. 9, September 2018, Pg. 1004 - 1014 http://hrmars.com/index.php/pages/detail/IJARBSS JOURNAL HOMEPAGE

Full Terms \& Conditions of access and use can be found at http://hrmars.com/index.php/pages/detail/publication-ethics 


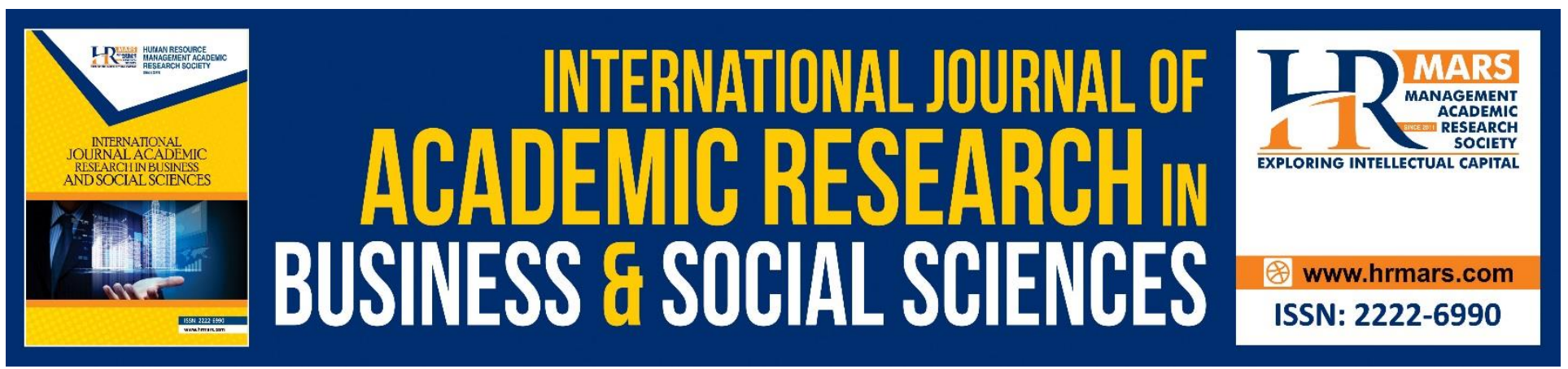

\title{
Assessing the Effect of Sales Force Automation on Sales Force Performance in the Sekondi-Takoradi Metropolis, Ghana
}

\author{
Nuhu Alhassan \\ Directorate of Internal Audit, University of Cape Coast, Ghana \\ Email: Nuhu.alhassan@ucc.edu.gh
}

\section{Abstract}

The general objective of the study was to explore how sales force automation (SFA) can be used to improve sales force performance (SFP). The study was conducted in in the STM of Western Region of Ghana in four Unilever distributing firms. These four companies had a combined sales force of 102 dedicated salesmen and saleswomen. The study adopted the descriptive survey design. In other to capture all the sales force in the area for the study, the researcher used the census method. However, at the end of data collection, the study was able to elicit data from 97 sales force persons resulting to 95.1 percent response rate. A questionnaire, made up of only close-ended items with five sections was the instrument used to collect data. Both descriptive and inferential statistical tools were used to analyse the data. The findings of the study revealed that effective use of SFA will lead to SFP in the organisation through improvement in sales persons' communication styles and adaptive selling behaviours which will in turn ignite the sales person's ability to use appropriate communication styles in increasing the sales performance of the company. It is recommended that the managers of the various key distribution companies of Unilever Ghana should ensure that all it salespersons are train to be able to apply information technology and to use it in supporting their selling and/or administrative activities. This will help them in recording, storing and retrieving customers and market information.

Keywords: Communication Style, Sales Force Automation, Sales Force Performance, Adaptive Selling Behaviour

\section{Introduction}

Globally, there is a growing interest by organisations in identifying the appropriate tools for their sales personnel that can improve their sales productivity, particularly Sales Force Automation (SFA) systems and customer relationship management tools (Anderson \& Oliver, 2014). According to Wedell and Hempeck (2016), this interest has become even more profound due to the direct 
relationship that always exists between sales and profitability. Tasked with the primary responsibility of selling their company's products and services, salespersons have always been at the forefront and a target for most technological innovations that are aimed at ensuring improvement in sales performance. One such technology that has gained considerable attention in sales management in recent times is the SFA technology (Wedell \& Hempeck, 2016).

The adoption of information technology (IT) via the use of SFA systems by sales organisations has been fast growing since the last decade. Now, more and more organisations are acquiring various forms of SFA devices for use by their field sales forces to better equip them for improved performance. As customers are demanding faster sales decisions, so are best-in-class companies realigning their sales force to meet customer demand by arming them with the necessary technologies to gain access to data in the global marketplace (Shoemaker, 2016).

Although marketing was among one of the first functional areas to adopt information technology, the utilisation of SFA technologies is a more recent phenomenon. SFA has been defined as the use of information technology by the sales force in selling and/or administrative activities (Buehrer, Senecal \& Pullins, 2013). Defined as such, SFA offers many potential benefits such as increases in sales effectiveness and efficiency, improved productivity, and enhanced customer relationship management (Buehrer et al., 2013). SFA systems utilise computerised hardware, software, and telecommunications technology to capture, access, analyses, and exchange high quality information in order to improve sales force productivity and effectiveness (Barua, Kriebel \& Mukhopadhyay, 2015).

According to Ahearne, Jelinek and Rapp (2015), studies into the relationship between SFA use and Sales Force Performance (SFP) have so far shown varying and inconclusive results. The varying conclusions reached by various studies into the relationship between SFA use and SFP suggest the need to better understand the mechanisms through which the use of sales technologies (ST) can lead to improved information technology (IT) which will in turn lead to improve performance.

In Ghana, SFA is an emerging phenomenon. Unilever Ghana Ltd. introduced its first mobile SFA system called the Ultra in 2005 (Unilever Ghana Limited, 2017). The Ultra is a small hand-held computer device that is used to record all sales transactions by the field sales force of all its Key Distributors across the country. Considering the peculiar case of Ghana as an emerging market for SFA technologies, the high cost of SFA implementation (Rouzies et al., 2016), the upfront investment that always has to made into SFA implementation, vis-à-vis the reports of a high incidence of SFA implementation failure (Wedell \& Hempeck, 2016), it is imperative for firms investing into SFA technologies in Ghana to understand beforehand how the use of an SFA technology leads to the desirable sales outcomes.

\section{Statement of the Problem}

A growing number of firms are investing into various forms of SFA devices to improve the efficiency and effectiveness of their sales forces. Though organisations spend substantial sums to equip their sales staff with SFA systems, there is still a high prevalence of failure of many SFA projects (Ahearne et al., 2015; Barua et al., 2015). According to Rouzies et al. (2016), this failure may be attributable to the general lack of clarity about the relationship that exists between SFA use and SFP. 
Various studies into the relationship between SFA use and sales performance have so far shown mixed results. For instance, Wade and Hulland (2014) report of only a marginal relationship between SFA usage and sales performance while Porter and Millar (2015) report of an insignificant effect of SFA use on performance. In their study, Ahearne et al. (2015) also provide empirical evidence that shows a curvilinear relationship showing a diminishing return between a salesperson's task performance and SFA usage level. This suggests that heavily relying on ST may not necessarily lead to better performance.

The relationship between SFA usage and sales performance is clearly an intricate one. Will merely using an SFA system help a salesperson to, for example, close more sales thereby increase overall turnover? As straight-forward as this may seem, no clear-cut answer can be provided in the literature. The inconclusive findings of previous studies coupled with the intricate nature of the influence of technology on sales performance have prompted the demand for further research into the subject matter.

Finally, most of the researches on SFA implementation are studies done mostly in developed countries with peculiar micro environmental settings, which largely differ from those that pertain in developing countries such as Ghana. It is, therefore, very vital to conduct this study to bridge this research gap. Considering Sekondi-Takoradi Metropolis (SKT) and Ghana for that matter, as an emerging market for SFA further makes it imperative to understand the mechanisms involved in the use of SFA.

\section{Objectives of the Study}

The general objective of the study was to assess how SFA can be used to improve SFP in STM, focusing on Unilever Ghana Limited. Specifically the study sought to:

1. Assess the relationship between SFA use, SFP, communication styles of a salesperson, and a salesperson's adaptive selling behaviour.

2. Assess the relationship between a salesperson's communication styles, adaptive selling behaviour, and sales performance

3. Examine the influence of SFA use, communication style of sales person's and adaptive selling behaviour of sales person's on sales forces performance.

\section{Significance of the Study}

As SFA technologies begin to gain prominence in Ghana, it is significant that its effects on sales performance be investigated to afford acquiring organisations sufficient understanding of the potential advantages of SFA technologies and how to use them effectively to reap these advantages. For those companies which have already implemented SFA and wish to understand how best to utilise it to improve their sales performance, this study hopes to be of immense benefit in providing invaluable insight into the causal factors underlying the use of SFA in selling. Finally, the findings and conclusions of this study would be beneficial to both researchers and academicians in providing them with substantial insight into how SFA impacts SFP and would also provide them with a firm basis for further studies into the subject matter in the future. 


\section{Scope of the Study}

The first delimitation of this study was that it was restricted to the sales force of only four Unilever key distributors with the SFA technology. Although restricting the study like this made it easier to control extraneous variables (e.g. different SFA systems, and different incentive plans), it may possibly render the generalisation of the findings of this study across all SFA technologies impossible or inappropriate. Secondly, defining SFA use in this study to mean acquiring /accessing and analysing information stored in the SFA device may be narrow. This is because the company or salesperson may be more interested in using other functions or applications of the SFA technology which may go beyond this definition. Finally, the particular type of SFA device (the Ultra) which formed the focus of this study may have software applications that may be significantly different from other SFA devices. This may render generations of the findings of this study to other SFA devices inappropriate in view of the possible differences in software design.

\section{Conceptual Framework}

The conceptual model of this study links key variables to explain how a salesperson's usage of SFA technology affects his/her sales performance. From the literature, it is apparent that SFA enabled SFP improvement which depends on the particular use of the SFA device. Figure 1 shows the relational linkages between SFA use, communication style, adaptive selling and sales force performance.

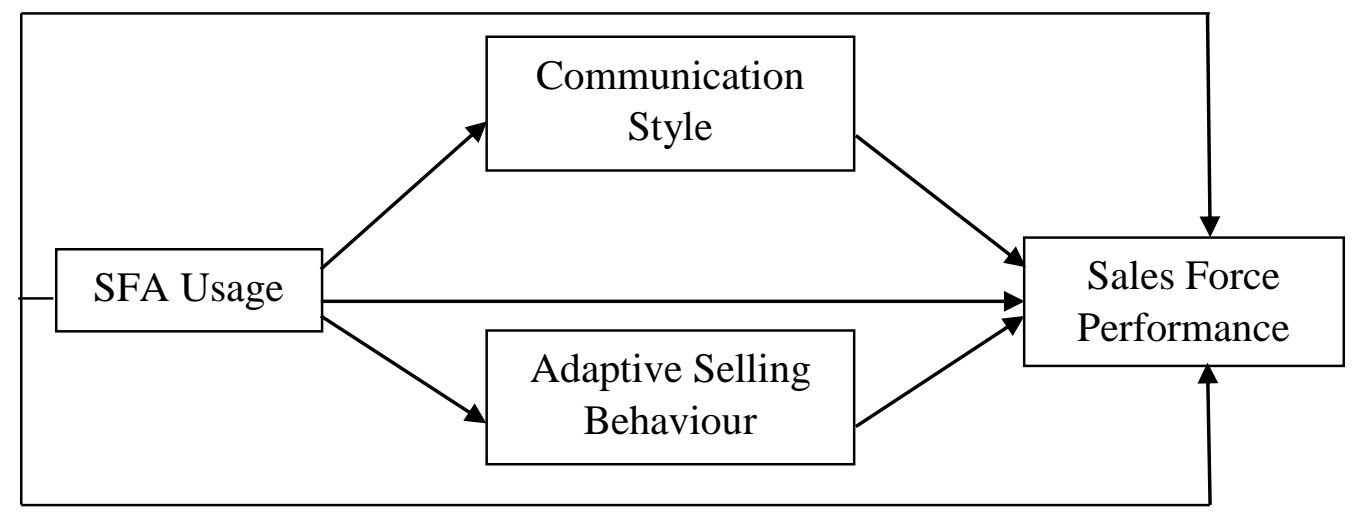

Figure 1: Influence of SFA, Communication Styles and Adaptive Selling Behaviour on SFP

Source: Author's construct, 2017

The basic premise of the conceptual model is that the use of SFA contributes positively to endresults sales effectiveness. It also recognises the mediating influences of a salesperson's communication style and adaptive selling behaviour and proposes that the use of SFA technology can affect a salesperson's performance indirectly through its positive impact on the salesperson's communication style and adaptive selling behaviour.

\section{Methodology}

The study adopted the quantitative approach. Since the study entailed a survey of the sales person's perception of the issues, situations and processes; the descriptive survey design was 
INTERNATIONAL JOURNAL OF ACADEMIC RESEARCH IN BUSINESS AND SOCIAL SCIENCES Vol. 8, No. 9, Sept. 2018, E-ISSN: 2222-6990 @ 2018 HRMARS

deemed the most appropriate. The population of the study comprised of all the 102 sales representatives of four Unilever key distributors in the STM in the Western Region of Ghana (Unilever Ghana Limited, 2017). The census method was used to capture all the 102 sales representatives of the four Unilever key distributions in STM. This method was deemed appropriate and feasible since the number of employees in the selected Unilever key distributors in the metropolis was small. Again, the census was necessary since the distributors were quite different from each other. Out of the 102 sale representatives, 89 of them were males while 13 of them were females.

\section{Instrumentation}

Questionnaire was the instrument used in collecting data from the respondents. In finding the reliability of the instrument, it was pre-tested in February, 2017, on a sample of 30 respondents made up of sales persons working at two of the key distributors of Unilever in the Accra Metropolitan Assembly. The sales force persons working with the key distributors of Unilever were selected because they share similar characteristics as those in STM. The study area was also selected due to its closeness and easy accessibility to the researcher. The Cronbach's alpha of the questionnaire generated was 0.841 .

\section{Data Collection Procedures and Analysis}

Before embarking on the field work, an informal familiarisation visits were made to the four key distributors of Unilever Ghana to confirm the number of sales personnel and to collect further and better information on their SFA. The questionnaires were personally administered by the researcher to all the 102 sales persons of the four key distributors of Unilever Ghana in the metropolis.

The questionnaire was preceded by an introductory letter soliciting information for purely academic work, and at the same time assuring participants of their anonymity in answering the questions. In some instances, the questionnaires were read and explained in order to meet the particular needs of respondents. Ten working days after the questionnaires were sent, a follow-up was made to encourage completion and return of the questionnaires. The completed questionnaires were collected back within a four-week period. However, most were collected at the same day it was administered. On the whole, out of the 102 respondents visited, 97 provided completed questionnaires; the remaining questionnaires were given back uncompleted. This resulted in 95.1 percent retrieval of completed questionnaires.

The data that were collected were first grouped and sorted. After that, they were coded using numerical values (coded manual) for the variable view of the Predictive Analytic Software Version 18.0. With the help of this software, the study used Pearson product moment correlation and multiple regression analysis to analyse the data.

\section{Results and Discussion}

The first specific objective of the study was to assess the relationship between SFA use, SFP, communication styles of a salesperson, and a salesperson's adaptive selling behaviour. Data on the variables were obtained using close-ended items. These items were measured numerically using unilinear scale such that one represents the least agreement to the issues while four represents the 
INTERNATIONAL JOURNAL OF ACADEMIC RESEARCH IN BUSINESS AND SOCIAL SCIENCES Vol. 8, No. 9, Sept. 2018, E-ISSN: 2222-6990 @ 2018 HRMARS

strongest agreement to the issues. Each of the variables was made up of many items that were pooled together using average responses. The results are presented in Table 1.

Table 1: Relationship between SFA Use, SFP, Communication Styles of a Salesperson, and Salesperson's Adaptive Selling Behaviour

\begin{tabular}{lcc}
\hline & \multicolumn{2}{c}{ Sales force automation use } \\
Variables & Correlation coefficient $(r)$ & Sig. \\
\hline Sales force performance & $0.678^{* *}$ & 0.000 \\
Communication styles of sales persons & $0.535^{*}$ & 0.014 \\
Sales person's adaptive selling behaviour & $0.391^{* *}$ & 0.002 \\
\hline
\end{tabular}

Source: Field Data, $2017 \quad * * p<0.01, * p<0.05 \quad(N=97)$

Table 1 shows that SFA used by the organisations in the study area was statistically significant and positively correlated with SFP $(r=0.678, p<0.01)$. The association between SFA use and SFP was strong. This means that the more an organisation uses SFA the higher that organisation will increase its SFP. The finding corroborates with the comments of Rouzies et al. (2016) who averred that the introduction of information technology into sales and marketing, organisations has been shown on many occasions to result in superior returns such as enhanced productivity, customer communication and relationships for a company when these technologies are embraced by the individual target users. Porter and Millar (2015) also reported that sales force automation systems are able to increase at least 10 percent to 30 percent in returns, while generating investment income of over 100 percent. The findings indicate that SFA can be an enabler for salespeople to access, acquire, and analyse information useful to achieving customer and organisational objectives.

Table 1 further shows that communication style of sales persons was statistically significant and positively correlated with SFA use $(r=0.535, p<0.05)$. The relationship between the two variables can be described as strong. This means that the more an organisation uses SFA the higher that organisation's sale persons will improve it communication styles to capture its customers so that they can understand better the new technology adopted by the organisation. The finding is consistent with the comments of Ahearne et al. (2015) who posit that salespeople utilise SFA to disseminate information and knowledge to customers. They added that with the increasing use of SFA to acquire/access and analyse information in the selling process, it may well be possible that this will eventually affect the manner in which the salesperson communicates with his/her customers which in turn might influence his/her sales outcome; hence, the argument that a salesperson's use of SFA has a positive relationship with his/her communication style.

Again, Table 1 indicates that there is a statistically significant positive and moderate relationship between sales person's adaptive selling behaviour and SFA use $(r=0.391, p<0.01)$. This may mean that the more an organisation is able to use SFA systems the more its sales person's will adapt appropriate selling behaviours that will help them capture more customers. The finding is consistent with that of Buehrer et al. (2013) who examined sales force technology usage, focusing on reasons, barriers, and support. Buehrer et al. (2013) found out that there is a positive relationship 
INTERNATIONAL JOURNAL OF ACADEMIC RESEARCH IN BUSINESS AND SOCIAL SCIENCES Vol. 8, No. 9, Sept. 2018, E-ISSN: 2222-6990 @ 2018 HRMARS

between sales person's adaptive selling strategies and sales performance which is as a result of the various modern technologies use by the firm. The finding further avers with that of Rouzies et al. (2016) who propose a framework to understand the effect of mediating mechanisms that mediate the use of sales technology and performance. One of the mediating variables in the model is a salesperson's adaptive behaviour. The results indicated that salesperson adaptability is related significantly with sales performance. Through adaptive selling, the salesperson may use different sales presentations across different selling encounters based on the information collected. He or she is able to draw on past learning from previous sales encounters to increase his or her effectiveness in the present situation.

The second specific objective of the study assessed the relationship between a salesperson's communication styles, adaptive selling behaviour, and sales performance. The results are presented in Table 2. As contained in the table, sales person's communication style was statistically significant and positively related to sales performance $(r=0.524, p<0.01)$. This means that the more sales person's use appropriate communication styles the higher the organisation will have high sales performance.

Table 2: Relationships between Sales Person's Communication Styles, Adaptive Selling Behaviours and Sales Performance

\begin{tabular}{lcc}
\hline & \multicolumn{2}{c}{ Sales performance } \\
Variables & Correlation coefficient $(r)$ & Sig. \\
\hline Sales person's communication styles & $0.524^{* *}$ & 0.003 \\
Sales person's adaptive selling behaviour & $0.499^{* *}$ & 0.001 \\
\hline
\end{tabular}

Source: Field Data, $2017 \quad * * \mathrm{p}<0.01 \quad$ (N = 97)

The findings may also mean that communication in sales practice provides the foundation for building relationships between the salesperson and the customer. In the context of relationship marketing, communication is a vital ingredient in building buyer-seller relationship (Barua et al., 2015). According to Shoemaker (2016), a salesperson can adopt various communication styles with its peculiar strengths and weaknesses which makes it possible for a particular style adopted by the salesperson to have an influence on the salesperson's sales performance, hence the proposition that there is a relationship between a salesperson's communication style and his/her sales performance.

Furthermore, Table 2 shows that there was a statistically significant positive relationship between sales person's adaptive selling behaviours and sales performance $(r=0.499, p<0.01)$. This means that the more sales persons are able to adapt appropriate selling behaviours the more their respective organisations will increase it sales performance. This finding is in line with that of Wedell and Hempeck (2016) who provide empirical evidence that suggests that the practice of adaptive selling is positively correlated with sales performance. However, the finding is incongruent with that of Rouzies et al. (2016) who found in their study that the effect of a salesperson's adaptability among other relational building constructs on actual sales performance and adaptive selling was not to be significantly related to sales performance. Rouzies et al. (2016) further found out that adaptive selling is positively correlated to sales outcome. It is clear that the practice of adaptive selling is positively 
INTERNATIONAL JOURNAL OF ACADEMIC RESEARCH IN BUSINESS AND SOCIAL SCIENCES Vol. 8, No. 9, Sept. 2018, E-ISSN: 2222-6990 @ 2018 HRMARS

correlated with sales performance. Therefore, there is a positive relationship between adaptive selling behaviour and sales performance. It can be proposed that salespeople who are able to use information to customise their selling approach for different customers should be in an advantageous position to reap sales success.

The last objective of the study examined the influence SFA, communication style of sales person's and adaptive selling behaviour of sales persons on SFP. First, SFA, communication style of sales person's and adaptive selling behaviour of sales persons were used as the independent variables while SFP was used as dependent variable. The study argues that the independent variables influence or contribute to SFP in the various organisations in the study area. The results are presented in Table

In the model, the three variables of the study as indicated earlier were entered as independent $\quad .4$ variables with SFP operating as dependent variable. The results as shown in Table 3 indicate that the standardised beta co-efficient for all the three variables were statistically significant. The most significant independent variable was SFA use (Beta $=0.491(0.039), p<0.01$ ), followed by communication styles of sales persons (Beta $=0.381(0.041), p<0.05$ ) and adaptive selling behaviour of sales persons (Beta $=0.294(0.044), p<0.01$ ) respectively.

Table 3: Influence of SFA Use, Communication Style of Salespersons, and Adaptive Selling Behaviour on SFP

\begin{tabular}{lccc}
\hline Variables & Beta & Std. Error & Sig. \\
\hline Sales force automation use & $0.491^{* *}$ & 0.039 & 0.000 \\
Communication style of sales persons & $0.381^{*}$ & 0.041 & 0.034 \\
Adaptive selling behaviour of sales persons & $0.294^{* *}$ & 0.044 & 0.005 \\
\hline Constant & \multicolumn{2}{c}{3.175} \\
$\mathrm{R}$ & \multicolumn{2}{c}{0.825} \\
$\mathrm{R}^{2}$ & \multicolumn{2}{c}{0.581} \\
Adjusted R & \multicolumn{2}{c}{0.563} \\
Source: Field Data, 2017 & $* * p<0.01 * p<0.05$ & $(\mathrm{~N}=97)$
\end{tabular}

Where the dependent variable $=$ SFP and Std. Error $=$ standard error

This means that SFA use, communication styles of sales persons and adaptive selling behaviour of sales persons are variables that influence SFP significantly. In addition, the unique proportional contribution of the three variables to sales force performance in the various organisations was 0.581 with an adjusted $R^{2}$ of 0.563 .

This means that SFA use, communication styles of sales persons and adaptive selling behaviour of sales persons are able to predict, influence or explain only 58 percent of the variance in SFP in the various organisations. It therefore, means that besides these variables identified, other factors not yet in the model have a chance of contributing or predicting about 42 percent to SFP in the organisations. The result suggests that the three variables use as independent variables alone do not contribute significantly to SFP in the organisations and that they do so when other variables are considered. 
The findings are in line with the suggestions of Ahearne et al. (2015) who suggest strongly the significant role of appropriate SFA usage in enhancing the performance of sales personnel in the information technology industry. The findings further corroborate with that of Porter and Millar (2015) who indicated that a formula for successful SFA implementation entails one that highlights on SFA usage: learning behaviour, relationship quality, and salesperson performance sequence. Their findings further indicate that adaptive selling has a significant direct influence on both relationship quality and salesperson performance. The results indicate that market information processing of sales personnel enhances their adaptive selling behaviours and relationships with their customers.

Similarly, the findings are congruent with that of Wedell and Hempeck (2016) who found that factors such as communication style, adaptive selling behaviour and customer information sharing use positively affects sales performance. It also provided a number of key insights. It showed that SFA use positively affects a salesperson's use of an interaction oriented communication style. This in turn positively affects the relationship quality between the salesperson and the customer which results in superior sales performance. These positive relationships confirm the capability of SFA to be used to access and analyse information to enhance customer relationship and to achieve sales success.

\section{Conclusions}

Most of the distributors in the study area with regard to the key distributors of Unilever Ghana have automated their sales activities. Specifically, they are now using computer hardware, software, and telecommunication devices in their selling and/or administrative activities. This improvement in relation to SFA in the long run has increased the distributors SFP. Therefore, effective use of SFA leads to SFP in the organisation through improvement in sales persons' communication styles and adaptive selling behaviours which in turn ignite salesperson's ability to use appropriate communication styles in increasing the sales performance of the organisation. Furthermore, it can be proposed that salespeople who are able to use information to customise their selling approach for different customers should be in an advantageous position to reap sales success. In a nutshell, SFA use, communication styles of sales persons and adaptive selling behaviour of sales persons in most organisations help in improving SFP of such organisation. However, there are other factors that also help in boosting the sales performance of organisations. 
INTERNATIONAL JOURNAL OF ACADEMIC RESEARCH IN BUSINESS AND SOCIAL SCIENCES

Vol. 8, No. 9, Sept. 2018, E-ISSN: 2222-6990 (C) 2018 HRMARS

\section{References}

Ahearne, M., Jelinek, R., \& Rapp, A. (2015). Moving beyond the direct effect of SFA adoption on salesperson performance: Training and support as key moderating factors. Industrial Marketing Management, 34(4), 379-388.

Anderson, E., \& Oliver, R. L. (2014). Perspectives on behaviour-based versus outcome-based sales force control systems. Journal of Marketing, 67(4), 76-88.

Barua, A., Kriebel, C. H., \& Mukhopadhyay, T. (2015). Information technology and business value: An Analytic and empirical investigation. Information Systems Research, 26(1), 3-50.

Buehrer, R. E., Senecal, S., \& Pullins, E. B. (2013). Sales force technology usage: Reasons, barriers, and support. Industrial Marketing Management, 34(4), 389-398.

Porter, M. E., \& Millar, V. E. (2015). How information gives you a competitive advantage. Harvard Business Review, 87(4), 149-160.

Rouzies, D., Anderson, E., Kohli, A. K., Michaels, R. E., Weitz, B. A., \& Zoltners, A. A. (2016). Sales and marketing integration. Journal of Personal Selling and Sales Management, 25(2), 113-122.

Shoemaker, M. E. (2016). A framework for examining IT-enabled market relationships. Journal of Personal Selling and Sales Management, 26(2), 177-185.

Unilever Ghana Limited. (2017). Annual report: Final draft. Unpublished annual report, Unilever Ghana, Accra.

Wade, M., \& Hulland, J. (2014). The resource-based view and information systems research: Review, extension, and suggestions for future research. MIS Quarterly, 28(1), 107-142.

Wedell, A., \& Hempeck, D. (2016). Sales force automation: Here and now. Journal of Personal Selling and Sales Management, 7(3), 11-16. 